\section{Od zarządzania twórczością do zarządzania własnym życiem. Wstęp do lektury Dziennika 1962-1989 Sławomira Mrożka}

Dorota Walczak
$\mathbf{R}$ eakcje krytyki na opasłe tomy Dziennika Sławomira Mrożka opublikowane w ostatnich latach ${ }^{1}$ były tak żywe i jednocześnie skrajne, że same w sobie są zagadnieniem interesującym dla badacza twórczości pisarza. Dariusz Nowacki, jeden z recenzentów, napisze, że skala rozpiętości ocen krytycznych diariusza będzie rozciągać się „od przesadnego entuzjazmu do całkowitego odrzucenia; zupełnie tak, jakby krytycy wypowiadający się podówczas na temat dzieła nie mieli do czynienia z tym samym przedmiotem"2. Pisząc natomiast o reakcjach czytelników, zasłyszanych przy kawiarnianym stoliku, Nowacki wspomni, że z jednej strony padały słowa o „oporze i lekturowej udręce, o tym, że tego się nie da czytać"3,

1 S. Mrożek Dziennik 1962-1969, t. 1, red. A. Doboszewska, A. Kasperek, Wydawnictwo Literackie, Kraków 2010; S. Mrożek Dziennik 1970-1979, t. 2, red. A. Kasperek, Wydawnictwo Literackie, Kraków 2012; S. Mrożek Dziennik 1980-1989, t. 3, red. A. Kasperek, Wydawnictwo Literackie, Kraków 2013.

2 D. Nowacki Rewers Mrożka, "Tygodnik Powszechny” 2012 nr 8, s. 28.

3 Tamże.

\section{Dorota Walczak}

- dr, interesuje się antropologią słowa w kulturze, literaturą dokumentu osobistego (ze szczególnym uwzględnieniem dzienników), zagadnieniami z pogranicza literatury i filozofii. Ostatnio publikowała w "Rocznikach Humanistycznych": Na początku był karnawał. $\mathrm{O}$ "Karnawale, czyli pierwszej żonie Adama"Sławomira Mrożka (2014). Kontakt: dorota. walczak@o2.pl 
z drugiej mówiono o dziwnym magnetyzmie, niepozwalającym oderwać się od książki. Dziennik Mrożka stał się zatem kością niezgody zarówno między zwykłymi czytelnikami, jak i między krytykami. Autorzy większości odczytań odnosili się negatywnie do zapisów diarysty, deprecjonując ich wagę i zarzucając ich autorowi ekshibicjonizm czy nawet „duchowy striptiz"4 . Inni podchodzili do Dziennika z nadmierną emfazą ${ }^{5}$. Bardzo niewielu natomiast zwróciło uwagę na praktyczny wymiar prowadzonych notatek, na to, jaką rolę odgrywały one w życiu pisarza.

Moja propozycja odczytania diariusza Mrożka jest polemiczna wobec większości głosów zabranych przez krytykę w sprawie odbioru Dzienni$k a$. Wynika to z faktu, że potraktowałam Dziennik przede wszystkim jako praktykę piśmienną, nie zaś jako tekst. Zapleczem teoretyczno-metodologicznym dla takiego ujęcia stały się dla mnie prace Philippe'a Lejeune'a i Pawła Rodaka. Spojrzenie na diariusz jako praktykę działania słowem pomaga zrozumieć teksty tak mocno skoncentrowane na osobie autora, tak wybitnie omfaloskopiczne jak Dziennik Mrożka. Rodak zaznacza, że przy spojrzeniu na dziennik jako praktykę na pierwszy plan wysuwa się składnik performatywno-funkcjonalny:

Nie zawartość zatem, nie tematyka, nawet nie rodzaj i struktura zapisów są tu najważniejsze, ale miejsce i rola dziennika w życiu osoby, która go prowadzi. Aby to dostrzec, uwypuklić nie tekstowy, lecz praktyczny czy nawet pragmatyczny charakter prowadzenia dzienników, trzeba pytać najpierw o ich funkcje: w życiu jednostki, a dalej w życiu społeczności, w przestrzeni kultury. ${ }^{6}$

4 J. Majcherek „Ja" nie do wytrzymania , ZZeszyty Literackie” 2011 nr 1, s. 190. Wśród tekstów, przeważnie recenzji, w których panuje niezadowolenie i/lub rozczarowanie lekturą, zob. m.in.: A. Horubała Żartowniś się nadyma, "Rzeczpospolita” 2010 nr 249, E. Morawiec Smutny więzień „ja”, "Gazeta Polska” 2010 nr 46, E. Morawiec Lamenty emigranta, "Niezależna Gazeta Polska. Nowe Państwo" 2012 nr 6-7, R. Pawłowski Lepsze auta już mnie nie wyprzedzą, "Gazeta Wyborcza" 2012 nr 19, Ł. Saturczyk Moje zewnętrzności, czyli próba diagnozy stanu twórczego pewnego znanego dramatopisarza na podstawie jego prywatnych zapisków, "Twórczość" $2012 \mathrm{nr} 7$.

5 Zob. przykładowo: A. Poprawa Mrożek jest gdzie indziej, "Gazeta Wyborcza” 2011 nr 216; T. Nyczek Mrożek zza Mrożka, „Przekrój” 2010 nr 38. Obydwie grupy czytelników, zarówno niezadowolonych, jak również entuzjastycznie ustosunkowanych do osobistych zapisów Mrożka, zwracały szczególną uwagę na bardzo intymny charakter dziennika pisarza, traktując go - jak sądzę - jako odmianę gatunku journal intime.

6 P. Rodak Dziennik osobisty jako praktyka piśmienna: działanie, materialność, tekst, w: Antropologia pisma. Od teorii do praktyki, red. Ph. Artières, P. Rodak, Wydawnictwa UW, Warszawa 2010, s. 182. 
W Rodaka podejściu do dzienników, które wykracza poza ich tekstowe rozumienie, bardzo ważną rolę odgrywa również analiza materialnej strony diarystycznych zapisów, gdzie przywiązuje się duże znaczenie do wyboru przez piszącego narzędzia pisma oraz nośnika notatek, a także do struktury dziennika, jego wyglądu (składnik materialny). Oczywiście interpretacja treści zapisów i ich języka oraz kompozycji w duchu tradycji filologicznej pozostaje wciąż użytecznym narzędziem metodologicznym (składnik tekstowy). Dopiero jednak ujęcie, które uwzględnia wszystkie trzy elementy funkcjonalnego i pragmatycznego podejścia (składnik performatywno-funkcjonalny, składnik materialny, składnik tekstowy) pozwala wedle Rodaka w sposób kompleksowy opisać codzienną praktykę piśmienną, jaką jest dziennik.

Podejście, które uwrażliwia badacza dzienników na ich materialny i pragmatyczny wymiar jest mi bliskie, dlatego chciałabym w swoim artykule spróbować odpowiedzieć przede wszystkim na pytanie o funkcję, jaką pełnił dziennik Mrożka w życiu pisarza. W tym celu pragnę przyjrzeć się również oryginalnej, materialnej postaci notatek, ponieważ materialność jest w tej nowej, antropologicznej perspektywie badawczej gatunkowym wyznacznikiem formy diarystycznej, niezbędnym wręcz dla zrozumienia jej specyfiki i roli.

Chciałabym w tym miejscu poddać krótkiej analizie początkowy zapis Dziennika Mrożka. Chodzi mi właściwie o „przedmowę”, by posłużyć się określeniem samego autora, która inauguruje całość przedsięwziętej praktyki diarystycznej. Żeby dobrze zrozumieć intencje autora, będę odwoływać się przede wszystkim do wersji oryginalnej, tj. maszynopisowej, ponieważ w opublikowanym Dzienniku mamy do czynienia z wersją skróconą? ${ }^{7}$ Mrożek tłumaczy w niej swoją decyzję o rozpoczęciu na nowo praktyki diarystycznej (wcześniej przez wiele lat prowadził młodzieńczy diariusz, który w pewnym momencie postanowił spalić):

7 Drukowana wersja Dziennika w ogóle różni się od wersji pierwotnej, jeśli chodzi o jej długość. Redaktor Anita Kasperek, prowadząca edycję Dziennika, twierdzi w jednym z wywiadów, że rękopisy i maszynopisy łącznie liczą prawie cztery tysiące stron (zob. M.I. Niemczyńska, A. Kasperek Magiczna maszyna Mrożka, "Gazeta Wyborcza” 2010 nr 223, s. 13). Tymczasem w okresie od 26 października 1962 roku do 29 listopada 1989 roku Mrożek zapisał 5134 karty. Jeżeli odejmiemy od tego 188 kart z zeszytu obejmującego okres podróży do Meksyku, który nie trafił do wydania na życzenie autora, pozostaje 4946 kart. Jak widać, pewna część zapisów diarystycznych Mrożka z lat 1962-1989 nie została opublikowana. Wydawca tłumaczy, że pisarz sam przygotował do druku notacje dziennikowe, które zdecydował się opublikować, a podczas prac redakcyjnych na przekazanym materiale wszystko było omawiane z jego autorem, który miał podejmować decyzje i autoryzować tekst swojego dziennika. 
Z trzech motywów wymienionych z grubsza, a właściwie czterech, bo o jednym zapomniałem, na tyle ważnym, że chciałem go wyodrębnić, motywem tym było planowanie i ustawiczne napominanie się, jak żyć i po co, pozostaje jeden: chodzi o arkę przymierza między tym co leci i toczy się, życiem, można powiedzieć, a pracą zawodową, o przygotowanie platformy pośredniej, podobnie jak chodzi gdzie indziej i komu innemu o przygotowanie stacji pośredniej do wylądowania na księżycu.

$\left(M_{1-2}\right)^{8}$

Dla porównania w wersji opublikowanej przywołany cytat brzmi następująco:

Z trzech motywów wymienionych poprzednio, a właściwie czterech pozostaje: jak żyć. Chodzi o arkę przymierza między tym, co leci i toczy się, życiem, można powiedzieć, a pracą zawodową, o przygotowanie platformy pośredniej, podobnie jak chodzi gdzie indziej i komu innemu o przygotowanie stacji pośredniej do wylądowania na Księżycu.

(I 6; 26 października 1962)

Jak widać, oryginalny fragment został skrócony, co jeśli nie zmieniło jego merytorycznej treści, to przynajmniej uczyniło ją niezrozumiałą dla czytelnika. W wersji opublikowanej niewymieniony poprzednio motyw prowadzenia zapisków: „jak żyć” został potraktowany jako ten, który ma wyznaczać kierunek nowo podjętej praktyki diarystycznej. Nie wiadomo wówczas, jaki miałoby to związek z "arką przymierza”, o której zaraz potem wspomina diarysta. Gdy sięgniemy do wersji oryginalnej, zobaczymy, że diarysta informuje w niej o pominięciu podczas wyliczania funkcji młodzieńczego dziennikopisania jednego ważnego motywu, ten motyw to: „jak żyć”. Nie on jednak ma wyznaczać kierunek podjętej na nowo praktyki. Diaryście „chodzi o arkę przymierza między tym, co leci i toczy się, życiem, można powiedzieć, a pracą zawodową", a zatem o ustanowienie w dzienniku czy też za pomocą dziennika swoistej zależności mającej łączyć życie pisarza z jego pracą zawodową. Świat wewnętrzny - wcześniej izolowany w pisarstwie autora Wesela w Atomicach - teraz stanie

8 Cytat pochodzi z maszynopisu; w dalszej części artykułu na oznaczenie fragmentów pochodzących z maszynopisu będę używać dużej litery M, po której pojawi się numer karty. Źródło: Fondation Jan Michalski pour l'Écriture et la Littérature/Archiwum Sławomira Mrożka, Montricher, Szwajcaria, sygn. B1 2. Z kolei cytaty z drukowanej wersji Dziennika będę oznaczać, umieszczając w nawiasie kolejno: numer tomu, strony oraz datę, pod jaką znajduje się cytowany fragment. 
się materiałem do obróbki literackiej, przedmiotem pracy twórczej, a dziennik będzie narzędziem do zarządzania tą pracą, przestrzenią dla poszukiwania sposobu na przetransponowanie osobistych doświadczeń na język literatury.

Staranne skomponowanie pierwszego zapisu, nazywanego przez samego Mrożka „przedmową, oraz podkreślenie na samym początku profesjonalnych motywów podejmowanego na nowo dziennikopisania to nie jedyne oznaki przemawiające za profesjonalizacją całego przedsięwzięcia. Kolejne to: wybór nośnika i narzędzia pisania. Od razu pragnę zaznaczyć, że dziennik Mrożka nie ma jednolitej postaci materialnej. Na całość składają się luźne kartki maszynopisu i rękopisu oraz zeszyty. Chciałabym zwrócić najpierw uwagę na nośnik pisania, jakim są luźne kartki. Rodak zauważa, że pisarze rzadko po nie sięgają na początku praktyki diarystycznej ${ }^{9}$. Używają luźnych kartek przede wszystkim, gdy przepisują swój dziennik, co powoduje, że tekst zmienia swój status i z osobistego przekształca się w literaturę. Zdarzają się jednak sytuacje (i tak jest w przypadku diariusza Mrożka), gdy pisarz od razu pisze na luźnych kartkach $^{10}$. Oznacza to - wedle Rodaka - że dziennik od początku jest „pisany”, tzn. „tworzony, konstruowany, kreowany"11, a nie "prowadzony”, co nadaje tekstowi literackiego charakteru. Podobnie zresztą jak wybór maszyny do pisania jako narzędzia praktyki diarystycznej. Niektórzy pisarze posługiwali się maszyną do przepisywania swoich dzienników albo wręcz prowadzili je przy jej użyciu, co zdaniem badacza również nadawało dziennikowi status tekstu literackiego. Dlatego też pisanie dziennika od samego początku na maszynie - tak rzadko spotykane wśród pisarzy - jest dla badacza cenną wskazówką interpretacyjną. Co ciekawe, o tym, że wybór maszyny nie był u Mrożka przypadkowy, informuje nas w „przedmowie” sam autor:

9 Zob. P. Rodak Międzyzapisem a literaturą. Dziennik polskiego pisarza wXX wieku (Żeromski, Nałkowska, Dąbrowska, Gombrowicz, Herling-Grudziński), Wydawnictwa UW, Warszawa 2011, s. 61-62.

Stan kartek maszynopisu dziennika Mrożka dowodzi, że rzeczywiście był on od początku prowadzony w sposób, który diarysta opisał w „przedmowie”, tj. przy użyciu maszyny do pisania i luźnych kartek. Kartki noszą ślady upływającego czasu, przez jaki leżały w teczkach; są pożółkłe, niektóre mają pozaginane rogi, ale ogólnie są w dobrym stanie. Najgorzej wypadają pierwsze karty maszynopisu. Diarysta pisał wówczas na papierze gorszej jakości (żółto-brunatnym, jakby z recyklingu). Już od 1963 roku sięga jednak po papier biały; niekiedy bywa on cieniutki niczym pergamin, z niego również diarysta w końcu zrezygnuje, by dalej prowadzić dziennik na papierze białym, ale grubszym. Diarysta numeruje poszczególne kartki, pisze na ogół jednostronnie, czasem na drugiej stronie pojawiają się dopiski długopisem. W maszynie używa czarnego albo niebieskiego tuszu, czasem również czerwonego, ale tylko do zapisania daty. 
Chodzi o arkę przymierza między tym co leci i toczy się, życiem, można powiedzieć, a pracą zawodową, o przygotowanie platformy pośredniej, podobnie jak chodzi gdzie indziej i komu innemu przygotowanie stacji pośredniej do wylądowania na księżycu. (Należę do pokolenia, dla którego pojawienie się samolotu na niebie było, nie powiem, sensacją, ale interesującym wydarzeniem). Właściwie tylko o to chodzi i dlatego choćby piszę na maszynie a nie moim ukochanym sposobem, jakimś dobrym piórem na dobrym papierze. Notowanie surowca nigdy nie było u mnie porządne (nie mówię teraz o spalonym świecie moich lat dwudziestych, gdzie było ono, na zasadzie baroku, wprost znakomite). Ale po co, właściwie, tłumaczę się tak i przed kim. Czy mam teraz ustalić cel tej przedmowy? Oczywiście, nie trzeba się okłamywać. Nie, nie chce mi się tłumaczyć. Warto by ustalić granicę, co powinno być sprecyzowane w słowach dla samego siebie (bo lekkomyślna odpowiedź „ja sobie i tak swoje wiem”, jest nieuczciwa, nie odpowiada zupełnie, to znaczy częściowo tylko, prawdzie. Swoje wprawdzie wiem, ale tylko w sekundzie, kiedy to wiem naprawdę, przemijanie, proszę pana) - a co jest tylko kokieterią wobec niepożądanego, (też sprawa niejasna) ale możliwego czytelnika. Ustalmy więc uczciwie: to, co zaczynam, może czytać każdy. Stąd to pisanie na maszynie (wtórnie jednakże, bo w pierwszym rzędzie chcę zachować czytelność dla siebie, kiedy będę wracał do dawniejszych kart, w godzinach pracy).

Dla porównania przywołam również wersję opublikowaną:

Chodzi o arkę przymierza między tym, co leci i toczy się, życiem, można powiedzieć, a pracą zawodową, o przygotowanie platformy pośredniej, podobnie jak chodzi gdzie indziej i komu innemu przygotowanie stacji pośredniej do wylądowania na Księżycu. Należę do pokolenia, dla którego pojawienie się samolotu na niebie było sensacją. I dlatego piszę na maszynie, a nie moim ukochanym sposobem, piórem i na dobrym papierze. Notowanie surowca nigdy nie było u mnie porządne. Ale po co właściwie tłumaczę się tak i przed kim? Oczywiście nie trzeba się okłamywać. Warto by ustalić granice, co powinno być sprecyzowane w słowach dla samego siebie, a co pominięte. Swoje wprawdzie wiem, ale tylko w sekundzie, kiedy to wiem naprawdę, czyli przemijanie, proszę pana. Ustalmy więc uczciwie: to, co zaczynam, może czytać każdy. 
Przyznaję, że dopóki nie zobaczyłam wersji maszynopisowej, miałam pewne trudności ze zrozumieniem zacytowanego fragmentu. Przykładowo, nie mogłam pojąć relacji między przynależnością diarysty do pokolenia, dla którego „pojawienie się samolotu na niebie było sensacją”, a jego wyborem maszyny do pisania jako narzędzia praktyki diarystycznej. Tymczasem okazuje się, że zdanie o przynależności do rodzącego się społeczeństwa postindustrialnego pojawiło się w nawiasie jako uzasadnienie dla zastosowania we wcześniejszym zdaniu metafory stacji kosmicznej. Tym razem jest już jasne, że diarysta wybrał maszynę do pisania nie dlatego, że należy do pokolenia, dla którego „pojawienie się samolotu na niebie było sensacją” (a właściwie nie sensacją, tylko interesującym wydarzeniem), ale dlatego, że miała ona ułatwić przygotowanie miejsca dla warsztatowych zapisków. Tym bardziej że „notowanie surowca" nie było do tej pory porządne. Mrożkowi nie wystarczyło wyznaczenie praktyce dziennikowej konkretnego zadania. Trzeba jeszcze, żeby to pisanie było staranne, utrzymane w porządku. Diarysta pisze na maszynie przede wszystkim ze względu na siebie, żeby zachować czytelność notatek, do których będzie powracał w czasie pracy nad utworami, o czym informuje w ostatnim zdaniu omawianego fragmentu z wersji pierwotnej, maszynopisowej. Niemniej w tym samym zdaniu wspomina, że pisze na maszynie również dlatego, aby zachować czytelność dla innych. I choć, jak sam przyznaje, nie jest to motyw wiodący, jego pojawienie się prowokuje do zadawania pytań o hipotetycznego czytelnika. Nie jest to z pewnością czytelnik bardzo wyraźnie obecny, z którym wchodzi się w interakcję i któremu „rzuca się wyzwanie”, tak jak u Gombrowicza ${ }^{12}$. Jest to natomiast „możliwy czytelnik" warsztatowych prób i literackich poszukiwań, które Mrożek zamierza uprawiać w dzienniku i które - jak sam zaznacza - „może czytać każdy”. To kolejny powód, dla jakiego pisarz sięga po maszynę: aby „możliwy czytelnik" (może nawet wydawca) nie miał podczas lektury zapisków problemów z ich rozczytaniem. Stosunek diarysty do przyszłego odbiorcy jego notatek jest kolejnym elementem przemawiającym za profesjonalizacją rozpoczynanej na nowo praktyki. To, co najbardziej intymne i prywatne, miało być w dzienniku pomijane, a to przy założeniu anonimowego czytelnika w przyszłości nie wydaje się wyjątkowym rozwiązaniem u osoby, która jak dotąd pilnie strzegła swojej prywatności. Bardziej istotny jest fakt, że pisarz od razu dopuszczał myśl o anonimowym odbiorcy swoich notatek. Nie jest

12 Zob. M. Czermińska Gombrowicz rzuca wyzwanie, w: tejże Autobiograficzny trójkq̨t: świadectwo, wyznanie, wyzwanie, Universitas, Kraków 2000, s. 33-44. 
zatem wykluczone, że już na samym początku podejmowanej na nowo praktyki dostrzegał realną możliwość opublikowania dziennika w przyszłości ${ }^{13}$. Tym bardziej że w chwili rozpoczęcia pisania diariusza na nowo Mrożek był już autorem znanym z opowiadań satyrycznych (Opowiadania z Trzmielowej Góry, Pótpancerze praktyczne, Stoń) i dramaturgiem, którego grywano za granicą. Ponadto w 1962 roku pisarz otrzymał Nagrodę Fundacji im. Kościelskich, co umocniło jego pozycję w środowisku literackim.

Analiza samej tylko „przedmowy” dowodzi, że od początku diarysta naznaczył powziętą praktykę profesjonalną motywacją. Dalsza lektura zapisów pokazuje natomiast, w jaki sposób Mrożek realizował w nich wszystkie najważniejsze funkcje pisarskiego dziennika ${ }^{14}$. Diariusz jako taki służył autorowi Tanga do zapisywania własnego pisania, do pisania o innych dziennikach. Stał się miejscem praktyki autokrytycznej i krytycznej, a także miejscem refleksji ogólnych, odnoszących się do uprawianej działalności artystycznej. Był ponadto kroniką pracy twórczej, warsztatem, laboratorium, archiwum twórczym.

Mrożek notował początkowo tylko te zdarzenia, z których mógł czerpać przesłanki do nowych utworów. Traktował dziennik jako archiwum twórcze, w którym gromadził opisy postaci, sytuacji, a także wątki, motywy i luźne myśli, które w przyszłości mogłyby zostać zużytkowane w twórczości. Pojawiały się również rozbudowane szkice i plany o zacięciu teoretycznym, w których pisarz rozważał kwestie techniczne, czyniąc tym samym z dziennika warsztat twórczy. Niekiedy wyróżniał omawiane kwestie w tekście; tak było w przypadku notatek poświęconych konstrukcji opowiadań, które diarysta zatytułował: „JAK NAPISAĆ OPOWIADANIE POZORNIE INTERESUJĄCE, czyli donos na samego siebie" (zob. I 16-18; 23 listopada 1962) albo sztuk teatralnych: „ROZWAŻANIA O NAPISANIU NOWEJ SZTUKI” (I 65-76; 5 lutego 1964). Teoretyczne rozważania dotyczące konstruowania postaci, sytuacji czy fabuł pojawiały się przede wszystkim w pierwszych latach prowadzenia Dziennika. Później funkcja dziennika jako warsztatu twórczego

13 Wszystkie trzy tomy ukazały się zresztą za życia pisarza: tom pierwszy obejmujący lata 1962-1969 został opublikowany w 2010 roku, tom drugi (1970-1979) w 2012 roku, tom trzeci (1980-1989) ukazał się na początku 2013 roku. Mrożek zmarł 15 sierpnia 2013 roku. oraz dziennika literackiego), jakie Rodak wyróżnił wśród dzienników pisarzy. W swojej książce badacz wymienia profesjonalne funkcje właściwe dziennikom pisarzy oraz innych artystów. Omawiając profesjonalne motywy prowadzenia dziennika przez Mrożka, posługuję się zamieszczoną u Rodaka typologizacją (zob. P. Rodak Między zapisem a literaturą, s. 52-56). 
sprowadzała się zasadniczo do gromadzenia pomysłów, propozycji i szkiców do przyszłych dzieł. Nie osiągały one jednak tak dużych rozmiarów jak w pierwszych latach praktyki diarystycznej, kiedy piszący wzbogacał je obszernymi komentarzami.

Warsztatowym uwagom, zawierającym m.in. pomysły do przyszłych dzieł, a także komentarze dotyczące konstruowania fabuły towarzyszyły zapisy kronikarskie. Diarysta odnotowywał w nich momenty rozpoczęcia pracy nad jakimś utworem, poszczególne etapy w jego tworzeniu i zakończenie, jak w przypadku opowiadania Wemtynie, we mtynie, mój dobry panie, filmu Amor czy niektórych dramatów, jak np. Rzeźnia, Emigranci, Polowanie na Lisa, Portret. Przykładowo pomysł na napisanie Polowania na lisa trafił do dziennika 8 lutego 1976 roku: „A może sztuka bajka? Lis, Kogut i ja. Tego jeszcze nie pisałem. Polowanie. Lis ukrywa się. Tu duże możliwości”. W tym samym wpisie dramaturg utrwala kolejne etapy tworzenia utworu, zapisuje dialogi, sugestie dotyczące poszczególnych scen. Ponad miesiąc później zanotuje: „W pięć dni napisałem Polowanie na lisa" (II 437; 14 marca 1976). Po roku Mrożek znowu wziął na warsztat ulubionych bohaterów. Tym razem dokumentacji procesu powstawania nowego utworu towarzyszyły dodatkowo uwagi o charakterze dyscyplinującym: „Ale napisz co, sztukę jaką albo co, bo bez tego nie będzie ani co jeść, ani o czym mówić. Jednoaktówka owa, Lis i Kogut. Od dawna już nie chce mi się o nich, a niby trzeba” (II 570; 7 marca 1977), „Pisarz powinien pisać. Piszmy więc, pisząc. Ławka. Lis i Kogut" (II 640; 15 listopada 1977). Omawiając profesjonalne motywy prowadzenia dziennika, nie sposób nie wspomnieć o notatkach, dokumentujących zapisywanie własnego pisania („Pisałem”/„Pisałam”). Jest to wedle Rodaka najbardziej znaczący rodzaj wpisów pojawiających się w dziennikach pisarzy ${ }^{15}$. Tego rodzaju wpisy pojawiają się również u Mrożka, co widać na powyższych przykładach. Mają na ogół charakter dyscyplinujący i są zorientowane na najbliższą przyszłość, wyrażają wolę piszącego. Zapisom kronikarskim nierzadko towarzyszą odwołania do własnej twórczości. „Zapisy autokrytyczne w dzienniku - zauważa Rodak pozwalają pisarzowi na ocenę [pop. red.] własnej twórczości, zestawianie jej z twórczością innych autorów, umiejscawianie jej na mapie prądów, szkół czy mód literackich"16. I u Mrożka odwołania do własnych utworów służyć będą ocenie dotychczasowego dorobku. Ponadto pisarz często będzie zestawiał

15 P. Rodak Między zapisem a literaturq, s. 52.

16 Tamże, s. 55. 
własną twórczość z twórczością innych dramaturgów lub kreślił uwagi na marginesie czytanych utworów:

Przeczytałem Fizyków Dürrenmatta. Co za ulga i jaka złość. Najlepiej od razu wyrzucić z siebie bluźnierstwo: taką sztukę mógłbym napisać, gdyby mi przyszło do głowy, że tylko na tym można było poprzestać. [...] Ale w tym są jeszcze gorsze rzeczy. Na razie stwierdziłem tylko, że arcydziełem okrzyknięto na półkulach utwór, który aż piecze w gardle, tak jest suchy i tak przypominający suchą bułę, którą człowiek zjada, a nie ma czym popić. Proszę bardzo. Złości mnie, że nie napisałem w zasadzie nic lepszego.

(I 13; 13 listopada 1962)

Praktyka krytyczna w Dzienniku dotyczyła nie tylko lektur związanych $\mathrm{z}$ dziedziną teatru, ale też z szeroko pojętą literaturą. Wśród czytanych pozycji znalazły się m.in. cudze dzienniki, w tym ulubione Dzienniki Franza Kafki oraz Ma vie Carla Gustava Junga (polski tytuł: Wspomnienia, sny, myśsi...), ale w większym stopniu wspomagały one samopoznanie niż pracę literacką.

Diarysta od początku traktował dziennik jako narzędzie mające przypominać o obowiązkach pisarza i mobilizować do pisania, a ostatecznie i przede wszystkim posłużyć wypracowaniu własnej formuły literackiej, która zapewniłaby mu miejsce w gronie najlepszych współczesnych dramaturgów. Żeby zrealizować ten ostatni cel, Mrożek przeprowadzał w diariuszu operacje na samym sobie, na żywej tkance swojego życia wewnętrznego, poddając nieustannie swoje ,ja" praktyce analizowania i opisywania, a także kontrolowania, upominania, rozliczania z realizacji wyznaczonych zadań, motywowania do zwiększonego wysiłku itp. Praca nad sobą w dzienniku miała być ściśle podporządkowana motywacji profesjonalnej. Próba całkowitej racjonalizacji swojej codziennej praktyki piśmiennej była jednak wbrew temu, czego tak naprawdę oczekiwał od niej sam piszący. Mrożek w niejednym wpisie przyznawał, że najlepiej odpowiadałby mu typ pisania o charakterze performatywnym, kiedy mógłby wykorzystać praktykę diarystyczną do celów autoanalitycznych oraz autoterapeutycznych. Niemniej niemal za każdym razem, gdy piszący dawał ponieść się nurtowi wewnętrznych przeżyć w swoich notatkach, pojawiały się uwagi dyscyplinujące i przypominające o „właściwej" funkcji dziennikopisania. Aż w końcu doszło w życiu pisarza do kilku przełomowych wydarzeń, które w istotny sposób wpłynęły nie tylko na jego życie, ale też na sposób prowadzenia zapisków. 
Jednym z takich wydarzeń, najważniejszym i najbardziej wstrząsającym, była dla artysty śmierć żony - Marii Obremby, która zachorowała nagle i po kilku tygodniach spędzonych w szpitalu zmarła 31 października 1969 roku. Analiza treści zapisów pozwala ustalić, że wpisy o charakterze profesjonalnym, tzn. związane z twórczością i podporządkowane funkcji archiwum twórczego, stają się po tym zdarzeniu rzadsze i mniej ważne (choć mniej ważne zaczęły stawać się już wcześniej). Mrożek przez dłuższy czas będzie miał problem z zaprowadzeniem w nich porządku: „Mniej niż kiedykolwiek - zapisze w niecały rok po śmierci żony - owe zapiski mają kształt, kierunek, pomysł, sens. Co się właściwie dzieje?" (II 17; 19 października 1970). Kilka lat później pisarz zacznie rozważać decyzję o wyprowadzce z mieszkania, które dzielił z małżonką, dopóki nie umarła:

Śniły mi się więc takie różne rzeczy... Może dlatego, a może dlatego także, że tak jest właśnie: coś chyba się kończy. Może za długo zostałem w tym mieszkaniu, jak za długo zostałem w Chiavari. Dotychczas zawsze tak było: $\mathrm{z}$ indolencji, z lenistwa, ze strachu - zawsze zostawałem gdzieś za długo. A potem tak się robiło nieznośnie, że wyprowadzałem się histerycznie, gwałtownie, desperacko. Ale teraz - dokąd? Z kim? (Wiadomo, oczywiście, z kim). Czy można tak długo mieszkać w mieszkaniu Mary? Zresztą to mieszkanie jest już tak nasycone mną, tyle już się stało w tym mieszkaniu, tyle nocy tu, to mieszkanie jest przejrzałe.

(M 6/19)

Choć zacytowany fragment nie trafił do edycji książkowej, zdecydowałam, aby go przywołać, ponieważ rzuca dodatkowe światło na rewizję praktyki piśmiennej Mrożka. Wspomnieniem nieżyjącej Mary pisarz symbolicznie zamyka pewien etap w swoim życiu (i również - jak za chwilę się przekonamy - w swoim dziennikopisaniu). Słowa o wyprowadzce ze wspólnego mieszkania, o tym, że „coś chyba się kończy, kreśli 30 lutego 1973 roku, a niedługo potem, bo 20 maja 1973 roku, „wyprowadza się" również z pisania na maszynie i wraca do zapisywania w zeszycie. Zmiana dziennikowego nośnika i narzędzia pisania miała niewątpliwy związek ze śmiercią żony artysty. Jednak pierwsze wpisy odręczne zaczęły pojawiać się na luźnych kartkach dopiero w 1971 roku, a zatem ponad rok po jej śmierci. Następne lata, począwszy od 1972 roku, to już okres dominacji rękopisu. Jak widać, zanim piszący na stałe sięgnął po zeszyt, przez kilka lat prowadził dziennik odręcznie na luźnych kartkach. Można by nazwać okres dzielący praktykę maszynopisania od 
praktyki rękopiśmiennej prowadzonej w zeszytach „okresem adaptacyjnym”, ponieważ diarysta oswajał się wówczas nie tylko z nową sytuacją życiową, ale również z nowym narzędziem, które wkrótce miało zastąpić maszynę i zapoczątkować erę prowadzenia zapisów w zeszytach. Okres adaptacyjny rozciągał się od 1971 roku do 20 maja 1973 roku, a więc do momentu, kiedy Mrożek rozpoczął zapisywanie w zeszytach. Należy jednak dodać, że jeszcze do 19 czerwca 1973 roku równolegle do wpisów w zeszytach diarysta prowadził notatki na luźnych kartkach, nie trafiły one jednak do wersji drukowanej diariusza.

Analiza zmiany materialnego nośnika Dziennika doprowadziła mnie do wniosku, że luźne kartki maszynopisu wzorowo spełniały swoją funkcję, dopóki dokumentowały postępy w pracy zawodowej dramaturga. Nie poradziły sobie jednak w obliczu życiowych perturbacji diarysty oraz nowych zadań stawianych praktyce dziennikopisarskiej. Zeszyt w większym stopniu niż luźne kartki potrafił zadośćuczynić potrzebom okaleczonej psychiki. Lejeune, zwolennik „szkoły luźnych kartek”, do której sam jako diarysta należał, przyznaje jednocześnie, że doskonale rozumie decyzje osób używających do notowania zeszytów:

zeszyt ma gwarantować, że wszystko się „zabliźni”, ułoży się w jedną całość. Zeszyt zszywany, klejony, oprawiony lub z metalową spiralą, zeszyt, na którym często umieszcza się nazwisko, zeszyt, który w wyobrażeniu autora daje to, co Paul Ricœur nazywa „tożsamością narracyjną” - stanowi obietnicę przynajmniej minimalnej jedności. ${ }^{17}$

W przypadku Mrożka gest sięgnięcia po kajet wyrażał od strony materialnej potrzebę zaprowadzenia porządku we własnym życiu, nadania mu ciągłości i jedności, którą zeszyt miał zagwarantować. Można pokusić się o stwierdzenie, że gestem tym diarysta zamknął ostatecznie okres „strojenia”, tj. szukania najwłaściwszej tonacji dla swoich notatek ${ }^{18}$. Nie oznacza to bynajmniej, że zapisy związane z twórczością pisarza przestały trafiać do dziennika.

17 Ph. Lejeune „Drogi zeszycie...", drogi ekranie..." O dziennikach osobistych, przeł. A. Karpowicz, M. i P. Rodakowie, Wydawnictwa UW, Warszawa 2010, s. 48. tymnych, zauważył, że początek diariusza może być "czasem jego strojenia". W tym sensie początek dziennika nie musi kończyć się na wpisie otwierającym całość przedsięwziętej praktyki. Może rozciągać się na dłuższy okres (zob. Ph. Lejeune „Drogi zeszycie...”, ,'drogi ekranie...", s. 68). 
Regina Lubas-Bartoszyńska zauważa, że „krąg tematyczny, związany z procesem twórczym nie daje spokoju prawie żadnemu pisarzowi - autorowi tekstów pamiętnikarskich (dzienników)" ${ }^{\prime \prime 9}$. Nie inaczej jest u Mrożka, który w kolejnych zeszytach będzie poświęcał zapisom związanym bezpośrednio z twórczością zdecydowanie mniej miejsca, ale jednak z nich nie zrezygnuje. Poza tym naiwnością byłoby stwierdzenie, że cała praca włożona w poznawanie siebie nie zostanie potem wykorzystana w twórczości literackiej. Pragnę w tym miejscu zwrócić jedynie uwagę, że już sama zmiana materialnego nośnika dziennika sugeruje przesunięcie akcentów w omawianej przeze mnie praktyce piśmiennej. Po kilku latach dziennik zaczął przedstawiać dla Mrożka wartość pragmatyczną, przy czym pragmatyczność ta w bardzo niewielkim już stopniu dotyczyła pracy literackiej. Była natomiast ukierunkowana przede wszystkim na czynności związane z poznaniem samego siebie, z zarządzeniem własnym życiem, które od początku współwystępowały i przenikały się z zapisami związanymi z zarządzaniem własną twórczością. I choć miały być podporządkowane profesjonalnej motywacji, szybko stały się „obsesją”, jak je określa w jednym miejscu sam diarysta, która zdominowała (ale nie wyeliminowała) inne funkcje prowadzenia dziennika, czyniąc z archiwum pracy pisarza przede wszystkim archiwum pracy nad sobą.

Paweł Rodak zauważa, że dziennik bardzo często bywa wykorzystywany jako narzędzie w praktyce autodydaktycznej, jaką jest praca nad sobą: ,taki dziennik służy m.in. do sporządzania wypisów i notatek z lektur, zajmowania wobec nich krytycznego stanowiska, wprowadzania w obręb własnego myślenia zawartych w nich informacji, sądów, teorii"20. Dziennik Mrożka również służył do zapisywania fragmentów z lektur. Diarysta cytuje w nim obficie i są to nieraz teksty o dużych rozmiarach. Jednocześnie odnosi się wrażenie, jakby wyborem lektur i fragmentów, które trafiają do dziennika, kierowała dyscyplina umotywowana czymś więcej niż tylko zamiarem edukacyjnym. Wybór tych, a nie innych tekstów scalała myśl, którą diarysta określał „obsesją szukania siebie" (II 67; 15 lutego 1972). Ta obsesja przenikała również inne działania słowne podejmowane w dzienniku, takie jak medytacja czy rachunek sumienia, w ogóle przenikała całą codzienną praktykę piśmienną, która bezpośrednio miała wpływać na życie diarysty. Towarzyszyła jej zatem motywacja egzystencjalna wraz ze wszystkimi najważniejszymi funkcjami,

19 R. Lubas-Bartoszyńska Style wypowiedzi pamiętnikarskiej, Wydawnictwo Naukowe Wyższej Szkoły Pedagogicznej, Kraków 1983, s. 31. 
jakie praktyka piśmienna o takim charakterze może spełniać: począwszy od funkcji autoanalitycznej (poznawanie siebie), poprzez funkcje porządkującą, dyscyplinującą, medytacyjną, terapeutyczną, a skończywszy na funkcji związanej z konstruowaniem własnej tożsamości i zarządzaniem własnym życiem. W Dzienniku Mrożka znajdziemy rozliczne wpisy wskazujące na performatywny charakter podejmowanej praktyki piśmiennej, która wyraźnie miała wpływać na życie piszącego. Oto kilka przykładów w formie haseł, mających przypominać o właściwej postawie wobec siebie (wyróżnienia pochodzą ode mnie): „Trzeba w ró ci ć d o s i e bi e” (I 189; 26 stycznia 1965), "[...] więc przede wszystkim koncentruję się na sobie" (I 192; 26 stycznia 1965), „«Postęp ować zgodnie z samym sobą»tobardzo niejasne. To znaczy, że najpierw należy dokładnie wiedzieć, jakim się jest, czyli do czego się zmierza” (I 324; 9 lutego 1966), „Kto wie czy cały ten proces tego, co się nazywa rozmaicie, dojrzewaniem, czy ja wiem jak, to właśnie owo szukanie, wyzwalanie się z siebie starego" (I 464; 25 marca 1967), „MUSZĘ zorganizować dwie strefy: «życie» i moje pisanie. «Życie» poddaje się jakiej takiej organizacji tylko przez «zajęcie się» sobą" (II 131; 2 sierpnia 1973), „D o r ze c zy, czyli do mnie. [...] Życie mniej mi się już przedstawia jako niewiadoma i błyskotliwa awantura, a raczej jako los, rodzaj losu, un trajet [franc. trasa do pokonania - przyp. wydawcy], który trzeba spełnić możliwie lojalnie” (II 168; 11 października 1973), „Mój Boże, ile życia już zmarnowanego przez to, że nie chciało mi sięw si ebie zagląd a ć dostatecznie głęboko i postępować według tego, co bym zobaczył. To trudne, ale jedynie zgodne z... z... z... prawdą?" (II 171; 14 października 1973), „«Poznaj samego siebie». A co potem?” (II 750; 21 września 1978), „Uciec do siebie? O mnia mea mecum porto” (II 780; 16 lutego 1979), "Jednak - kiedy przestanę zaj mować się sobą - nie będę się już zajmował niczym. Moje zainteresowanie innymi jest zbyt nikłe" (II 781; 20 lutego 1979), „Zanikanie namiętności. [...] A może - później? - najbardziej pożądana naturalna ewolucja. Powrót do siebie sam e g o” (II 792; 3 lipca 1979), „Więc nigdy dosyć s tu di ó w nad e go. [...] Te studia to nie egoizm, ale właśnie coś całkiem przeciwnego. Choć nieraz mogą się z egoizmem mylić albo rzeczywiście mieszać. I to jest prac a $\mathrm{na}$ c ałą resztę ży cia” (III 369; 26 lutego 1983), "O koncentracji jako broni absolutnej: świat jest rozproszony, ludzie są rozproszeni, wszystko jest rozproszone, ty jesteś rozproszony. W każdej konfrontacji, także ze sobą samym, [...] - będziesz górą, jeśli skondensujesz się odpowiednio" (III 754; 2 czerwca 1988), „Wszelkie s a mopoprawianie się, ja etc., i tym 
podobne s a mo d o s k o n a l e n i a” (III 788; 30 listopada 1988), „Stary obowiązek - ambicja, by «coraz lepiej» (s elf - i mprove me nt etc.). Coraz mniej w zgodzie z wiekiem. Teraz już o co innego chodzi" (III 828; 17 kwietnia 1989) itp.

Powyższe przykłady pokazują, jak konsekwentnie Mrożek zmagał się z samym sobą na przestrzeni wielu lat i jak ogromną pracę wykonywał, aby realizować określony projekt budowania siebie. Jest to obraz pisarza znany - do chwili publikacji dziennika - jedynie jemu samemu, a być może jeszcze kilku najbliższym osobom. Stąd wrażenie wielu krytyków, jakoby Mrożek dopuścił nas w swoim Dzienniku tak blisko, jak nigdy dotąd. Rzeczywiście autor Tanga pokazuje się w prywatnych notatkach od innej, nieznanej dotąd strony. Nie są to jednak zapisy o charakterze bardzo intymnym. Są to zapisy pisarza nieustannie pracującego nad sobą, nieugięcie budującego swój świat wewnętrzny, co widać w powracających zwrotach do siebie samego. Pobrzmiewa w nich egotyzm, a może nawet egoizm graniczący z megalomanią. Jakkolwiek by nazwać Mrożkowe zamiłowanie do zajmowania się sobą, jest ono naznaczone głodem samowiedzy, jest pewną postawą wobec siebie, która charakteryzuje się zwróceniem spojrzenia ku własnemu wnętrzu i w wielu miejscach przypomina antyczne „praktyki siebie" podejmowane przez przedstawicieli różnych szkół filozoficznych, funkcjonujących w grecko-rzymskiej kulturze początków cesarstwa rzymskiego ${ }^{21}$. Jednymi z najbardziej charakterystycznych praktyk, rozwijanymi zasadniczo przez stoików, epikurejczyków i cyników, były: pisanie, lektura, rachunek sumienia, medytacje i ćwiczenia w śmierci. Michel Foucault w swojej filozoficznej koncepcji starożytności podkreślał, że pomagały one w zarządzaniu własnym życiem w taki sposób, aby nadać temu życiu piękny kształt, aby uczynić siebie swoim własnym dziełem. Tak rozumiana "troska o siebie" przenika również całość prywatnych zapisów Mrożka, w których można zaobserwować ślady takich praktyk jak pisanie, lektura, rachunek sumienia, medytacja, a nawet ćwiczenie się w śmierci. Ich

21 Problematykę antycznych, greckich i rzymskich "praktyk siebie” podejmował w wielu swoich tekstach Michel Foucault. Najwięcej miejsca poświęcił im podczas wykładów wygłaszanych w latach 1981-1982 w Collège de France i opublikowanych w wersji książkowej (zob. M. Foucault Hermeneutyka podmiotu. Wykłady w Collège de France 1981-1982, przeł. M. Herer, oprac. F. Gros, PWN, Warszawa 2012). Problematyką ćwiczeń duchowych wcześniej od Foucaulta zainteresował się Pierre Hadot, który uczynił z nich ważny element swojej koncepcji filozofii starożytnej (zob.: P. Hadot Czym jest filozofia starożytna?, przeł. P. Domański, Fundacja Aletheia, Warszawa 2000; P. Hadot Filozofia jako ćwiczenie duchowe, przeł. P. Domański, Fundacja Aletheia, Warszawa 2003). 
obecność czyni z notacji dziennikowych nie tylko narzędzie nieustannej pracy nad sobą, ale również narzędzie, które pod wieloma względami przypomina praktyki duchowe starożytnych.

Śledząc maszynopis i rękopis dziennika, można zauważyć różnice także w sposobie jego prowadzenia. O ile pisaniu na maszynie towarzyszą skreślenia w tekście, mające postać wyiksowanych fragmentów, o tyle rękopis w zeszytach jest ich prawie całkiem pozbawiony. To kolejny argument ujawniający napięcia w praktyce piśmiennej Mrożka, które trudno byłoby zauważyć, gdyby opierać się wyłącznie na analizie tekstowej. Trudno tym bardziej, że książkowa edycja dziennika nie zawiera znacznej części wpisów pochodzących z okresu adaptacyjnego. A był to niezwykle burzliwy okres w życiu uczuciowym pisarza, na który przypada m.in. lato 1972 roku spędzone w Sologne z ukochaną. Diarysta napisze o nim: „Raz w życiu byłem zakochany naprawdę. Boże, jak wtedy wiedziałem, lato w Sologne, 1972, że to było ostatnie niebo" (II 224; 11 stycznia 1974). Dylematy osobiste, jakie piszący w tamtym czasie przeżywał, znajdowały odzwierciedlenie w sposobie prowadzenia zapisków, w których zaczął dominować rękopis na luźnych kartkach. Nie został on jednak dołączony przez Mrożka do książkowej wersji Dziennika. Podobnie zresztą jak zeszyt obejmujący okres od 30 maja 1974 do 1 września 1975 roku (sugerując się datami i numeracją kolejnych notatników), zawierający najprawdopodobniej więcej szczegółów z prywatnego życia pisarza. Czy dlatego Mrożek nie oddał tego notatnika do archiwum? Swoiste ocenzurowanie dziennika oddanego do druku może oczywiście świadczyć o tym, że jego autor nie chciał ujawniać wszystkiego, co w nim zapisywał, może również świadczyć o chęci literaryzacji codziennej praktyki piśmiennej z chwilą podjęcia decyzji o jej opublikowaniu w postaci książki. Dla mnie jest jednak przede wszystkim kolejnym argumentem przemawiającym za funkcjonalizacją i ukierunkowaniem tejże praktyki w trakcie jej prowadzenia na dokonywanie zmian we własnym życiu, z którym pierwotnie, tzn. zanim Mrożek postanowił nadać notacjom dziennikowym nieco inną formę i opublikować je w postaci książki, codzienna praktyka piśmienna była związana w stopniu większym, niż się nam wydaje.

Kończąc swoje rozważania, pragnę zauważyć, że badanie praktyki diarystycznej Mrożka od strony performatywno-funkcjonalnej i materialnej pozwoliło nie tylko zaobserwować zmiany, jakie nastąpiły w jej obrębie po śmierci żony pisarza, Marii Obremby. Pozwoliło dodatkowo uwypuklić specyfikę i funkcje, jakie codzienna praktyka piśmienna pełniła w życiu pisarza. Pozwoliło dostrzec, że istotny wpływ na jej charakter miało to, w czym oraz 
przy użyciu jakich narzędzi była prowadzona. Użycie maszyny i luźnych kartek od razu sugeruje badaczowi zamiar profesjonalizacji czy nawet literaryzacji podejmowanej przez diarystę praktyki.Zmiana dziennikowego nośnika i narzędzia pisania, a także świadomość istnienia w obrębie praktyki piśmiennej fragmentów, których sam autor nie zdecydował się oddać do publikacji, to dla badacza ważne sygnały. Ważne, ponieważ tym samym status dziennika już w trakcie jego prowadzenia zmienia się tak, że dziennik przestaje być przede wszystkim dziennikiem pisarskim, a nabiera cech dziennika osobistego pisanego mniej na użytek własnej twórczości, a bardziej dla siebie i dla własnego samopoznania. Trudno byłoby domyśleć się tego $\mathrm{z}$ książkowej edycji, ponieważ nie obejmuje ona znacznej części notatek pochodzących z okresu, który nazwałam „adaptacyjnym” oraz zeszytu obejmującego okres od 30 maja 1974 roku do 1 września 1975 roku. Koncentrując się na samej tylko analizie tekstowej, łatwo z kolei o przeoczenie zmian, jakie zachodziły w charakterze zapisów. Dla czytelnika książkowej edycji mogą one wydać się tak subtelne, że nieomal niewidoczne. Tym bardziej, że nie obcuje on z zapisami Mrożka w postaci, w jakiej zostały pierwotnie sporządzone. Sądzę jednak, że nawet ich znajomość nie spowodowałaby zasadniczych zmian w zaproponowanym przeze mnie odbiorze Dziennika jako praktyki piśmiennej, która miała odgrywać w życiu pisarza znaczącą rolę. Polegała ona nie tylko na zarządzaniu własną twórczością, ale przede wszystkim na zarządzaniu własnym życiem tak, aby nie dać pochłonąć się przez jego absurdalność, aby nadać temu życiu kształt możliwie najlepszy, aby uczynić ze swojego życia dzieło. 


\section{Abstract}

\section{Dorota Walczak}

INDEPENDENTSCHOLAR

From Managing Work to Managing Life: Reading Sławomir Mrożek's Dziennik [Diary] 1962-1989

Walczak presents a comprehensive reading of the diary of the Polish dramatist and writer Sławomir Mrożek (1930-2013). The three-volume Dziennik [Diary], covering the years 1962 to 1989, was published by Wydawnictwo Literackie in 2010 to 2013. In this polemical reading Walczak treats Dziennik first of all as a writing practice, not as a text. The theoretical and methodological background to this approach is based on the work of Philippe Lejeune and Paweł Rodak, who emphasize the practical or even pragmatic nature of keeping journals. Walczak tackles questions about the diary's function in the writer's life.

\section{Keywords}

Sławomir Mrożek, diary, journal, writing practice 